\title{
Development and validation of the first brazilian french-based asphalt mix complex modulus and fatigue test apparatus
}

\author{
Breno Barra', Leto Momm², Yader Guerrero³, Yves Brosseaud ${ }^{4}$, Gustavo Momm ${ }^{5}$ \\ 1Post-Graduation Program in Engineering and Mechanical Sciences, UFSC, Joinville, Brasil, breno.barra@ufsc.br \\ 2Post-Graduation Program in Engineering and Mechanical Sciences, UFSC, Joinville, Brasil, leto.momm@gmail.com \\ ${ }^{3}$ Post-Graduation Program in Engineering and Mechanical Sciences, UFSC, Joinville, Brasil, yagcivil@gmail.com \\ ${ }^{4}$ Institut Français des Technologies des Transports, de l'Aménagement et des Réseaux, Nantes, France yves.brosseaud@ifsttar.fr \\ 5 Petróleo Brasileiro S.A. - Petrobrás, Device Engineering Department, Santos, Brasil, gustavo.momm@gmail.com
}

\section{Recebido:}

4 de janeiro de 2019

Aceito para publicação:

9 de maio de 2019

Publicado:

15 de maio de 2020

Editor de área:

Francisco Thiago Aragão

\section{Keywords:}

Validation,

Complex Modulus,

Fatigue,

Test Apparatus.

\begin{abstract}
The main aim of this paper is to present the development and validation procedures of the first brazilian french-based asphalt mix complex modulus and fatigue test apparatus, so-called FADECOM, in order to demonstrate the effective application of the results obtained in pavement design procedures. Magnetic sensitive Hall Effect non-contact captors determine amplitude displacement, while loading cells capture force amplitude by a diaphragm system. Independent cooling and heating chambers assure a precise temperature control comprising a range from -30 으 to above 100 으 $\mathrm{C}$ with an accuracy of 0.1 으. A frequency inverter controls the emission of pulses usually set from $1 \mathrm{~Hz}$ to $30 \mathrm{~Hz}$. For validating the apparatus, a scientific cooperation agreement was dealt with French Institute of Transportation Sciences and Technologies, Development and Road Network (IFSTTAR), in which specimen samples were tested in both UFSC and IFSTTAR laboratories. The crossed-results obtained indicate an excellent performance and accuracy of FADECOM apparatus, presenting variations around just 3 microstrains in determining fatigue strains at $10^{6}$ cycles $\left(\varepsilon_{6}\right)$ and less than $10 \%$ related to the complex stiffness modulus, demonstrating huge accuracy of the FADECOM apparatus and its practical feasibility to be applied in pavement design procedures, based on the technical principles of French methodology.
\end{abstract}

DOI:10.14295/transportes.v28i2.1927

OPEN

ACcess

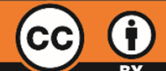

\section{INTRODUCTION}

Understanding rheological-mechanical properties of asphalt mixes at different temperatures and loading frequencies is essential, due to influence they exert directly on the linear viscoelastic behavior of these materials (Barra, 2009; Momm, 1998; Sayegh, 1965; Huet, 1963).

The constant need of formulating asphalt mixes able to support the growing, continuous and intense loading axle levels of the traffic fleet worldwide, have been leading to research the effect of high consistent asphalt binders in increasing the stiffness dynamic (or complex) modulus and resistance to fatigue, which is the main phenomenon responsible for the rupture of pavement structures in the field (Barra et al., 2016; Barra et al., 2012; Domec, 2005; Rudensky, 1997). 
French methodology was chosen to be a reference, due to present a scientific, officially published and proven close field-laboratory rate (Manuel LCP, 2007; AFNOR NF EN 12697-24, 2012; AFNOR NF EN 12697-26, 2012), giving strong credibility to the results obtained.

Considering the above-mentioned principles, the first french-based dynamic stiffness modulus and fatigue test apparatus, so-called FADECOM, has been conceived by the Pavement Research and Development Group (GDPPav), pertained to Federal University of Santa Catarina, Campus UFSC/Joinville, endeavoring for more than a decade in continuous researches on physical and mathematical models, as well as on numerical simulations, taking into account principally the technical principles of French pavement design methodology, as demonstrate ahead in this manuscript.

Among particular and notable characteristics of the apparatus are its easy portability, despite have a robust and stable stainless steel framework, the capability to carry out complex stiffness modulus and/or fatigue tests with four trapezoidal specimens simultaneously, in continuous mode with displacement amplitude control and generation of sinusoidal loading and displacement signals.

Furthermore, it consists in the first scientific initiative outside France to propose a project capable to carry out dynamic (complex) stiffness modulus and fatigue tests in the same apparatus, using trapezoidal specimens tested in continuous mode and with displacement amplitude control, also able to perform both mentioned tests under environmental conditioning states, i.e., in wet and dry situations.

\section{Technical charateristics of the apparatus}

FADECOM apparatus has a solid stainless steel base, which supports a climatic chamber made of polyurethane. The temperature inside this chamber is adjusted by an automatic digital controller that commands two distinct climatic systems: one for heating and another for freezing. Hence, when one of these systems is being adjusted for operation, the other is deactivated automatically, thus guaranteeing the desired temperature for the tests.

With this automatic digital controller commanding both climatic systems, it is possible to carry out tests with temperatures ranging from $-30^{\circ} \mathrm{C}$ to higher than $100^{\circ} \mathrm{C}$. The temperature set during the tests is supplied by 9 thermocouples placed at different points into the chamber with an accuracy of $0.1^{\circ} \mathrm{C}$.

A frequency inverter is responsible for adjusting the frequency of the tests, which commands a 6-pole induction motor connected to two eccentric axles. The rotational movement of the eccentric axles generates a force that is transmitted gradually to a set of interlocking pieces until reach the oscillator rods connected to the specimens (Figure 1).

The force transmitted gradually to the oscillator rods applies a back and forth displacement in the top part of the specimens, which generates a sinusoidal loading signal, i.e., alternating flexion effort. The loading and displacement signals are captured simultaneously by loading cells and Hall effect sensors, respectively (Figure 2).

It is also possible to perform complex modulus and fatigue tests under conditioning states, simulating alternated or continuous wet and dry environmental situations, submitting the trapezoidal specimens to a prior saturation process into water using a vacuum pomp pressure of $350.0 \mathrm{~mm} / \mathrm{Hg} \pm 5.0 \%$ immediately before the beginning of the tests, in order to achieve a given 
saturation degree of the air void content of each specimen. After this pre-conditioning stage, the specimens are immersed into water during the tests, in an apparatus specifically designed for the placement of the water reservoirs (Figure 3 ).

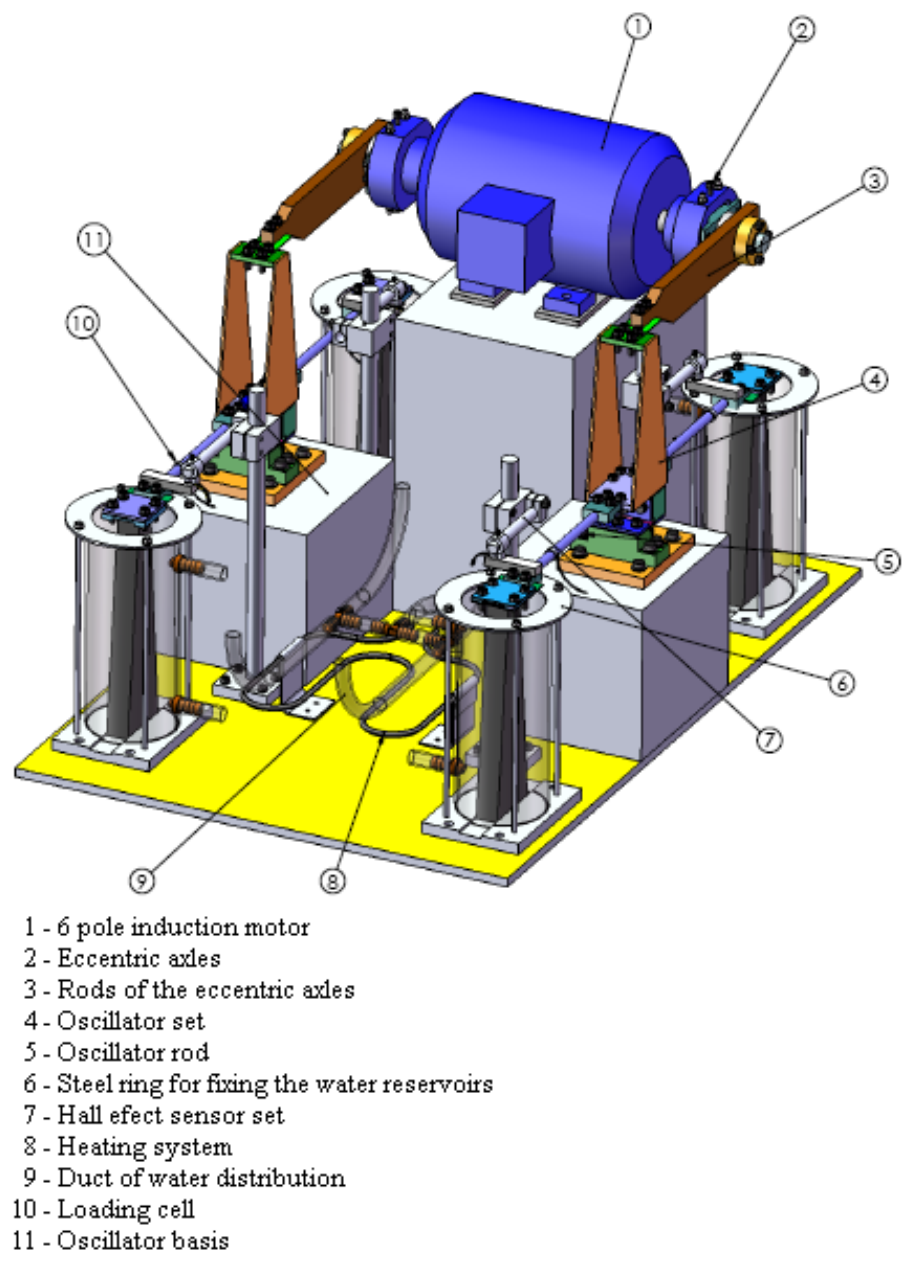

Figure 1. Set of Pieces Involved in the Test Procedures

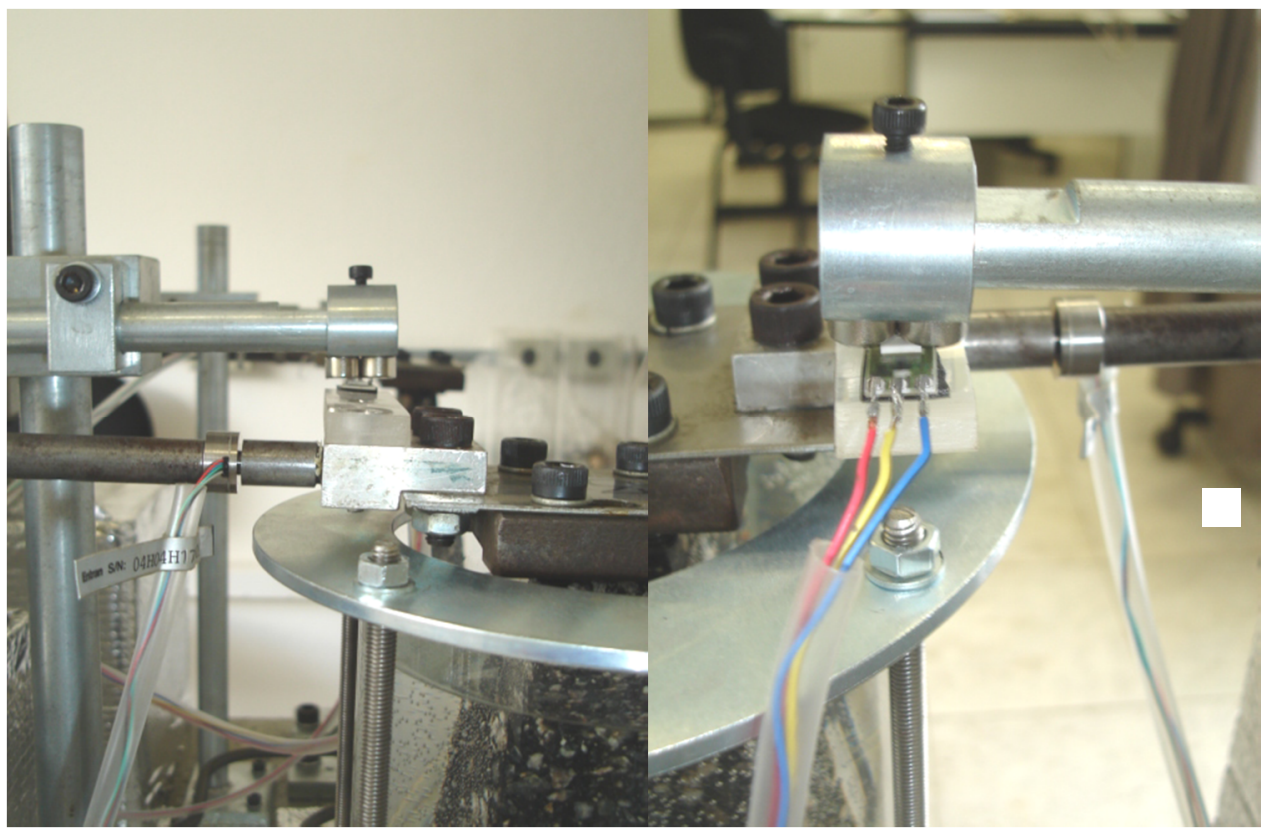

Figure 2. Detailed view of the loading cell and Hall Effect sensor 


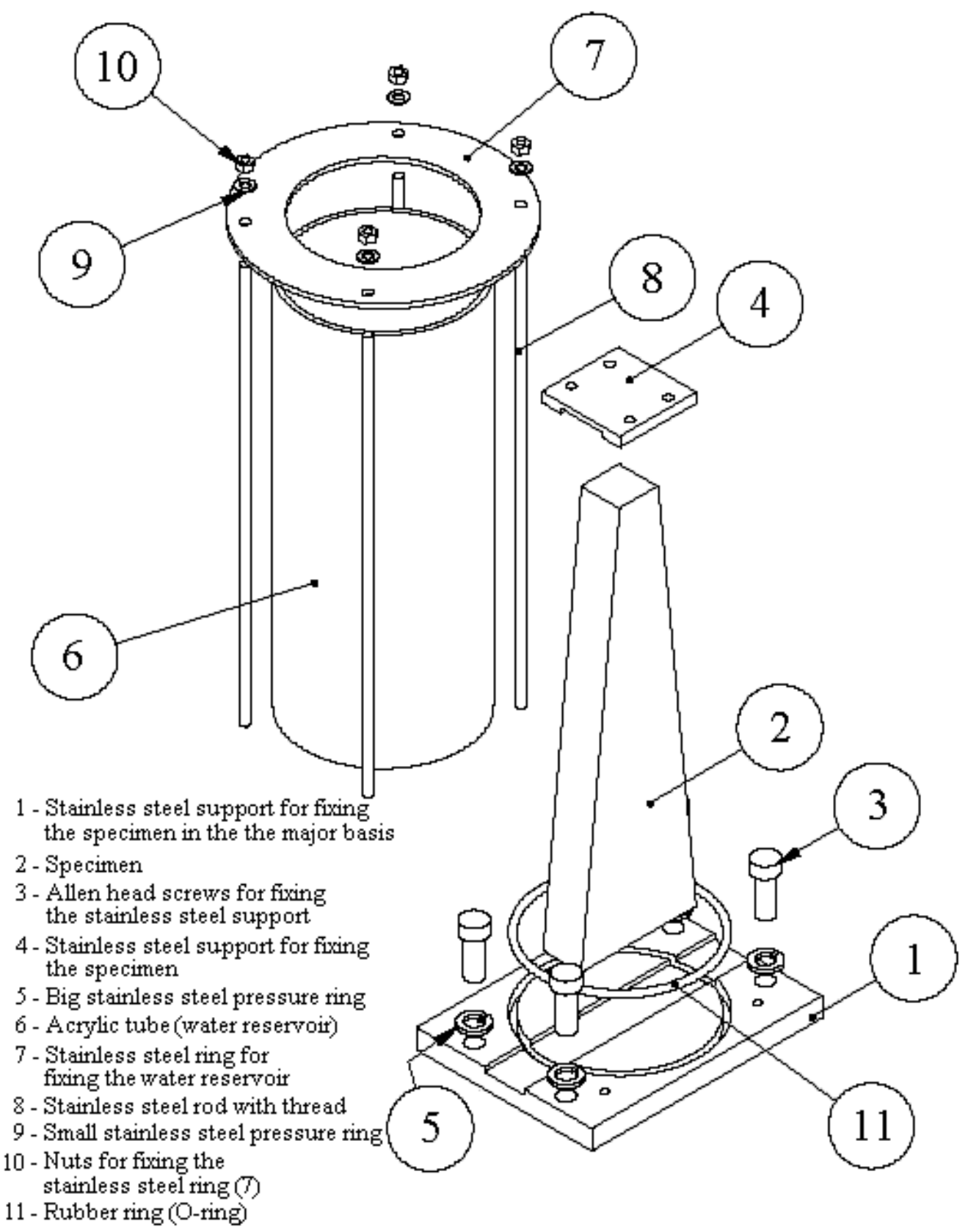

Figure 3. Overview of the environmental conditioning apparatus

A data acquisition system captures the electrical pulses sent by the loading cells and by the Hall effect sensors with a sample frequency of $640 \mathrm{~Hz}$. A computerized terminal programmed in a platform language $\mathrm{C}^{++}$converts these pulses into values of force and displacement to a graphical interface in Excel sheet in real time, as for complex modulus (Figure 4) as for fatigue tests (Figure 5).

It is important to emphasize the sharpness of the signals captured by the loading cells and Hall effect sensors (Figures 4 and 5), demonstrated through good definition of the curves, with low noise level, guaranteeing suitable accuracy of the measurements carried out.

However, it is perceivable the increase of the noise level in phase III of the fatigue tests (Figure 5), taking into account Hall effect sensor responses, because at this stage the specimens have reached the structural collapse, in which the displacement amplitude control becomes disordered within the magnetic spectrum of the referred sensors. 


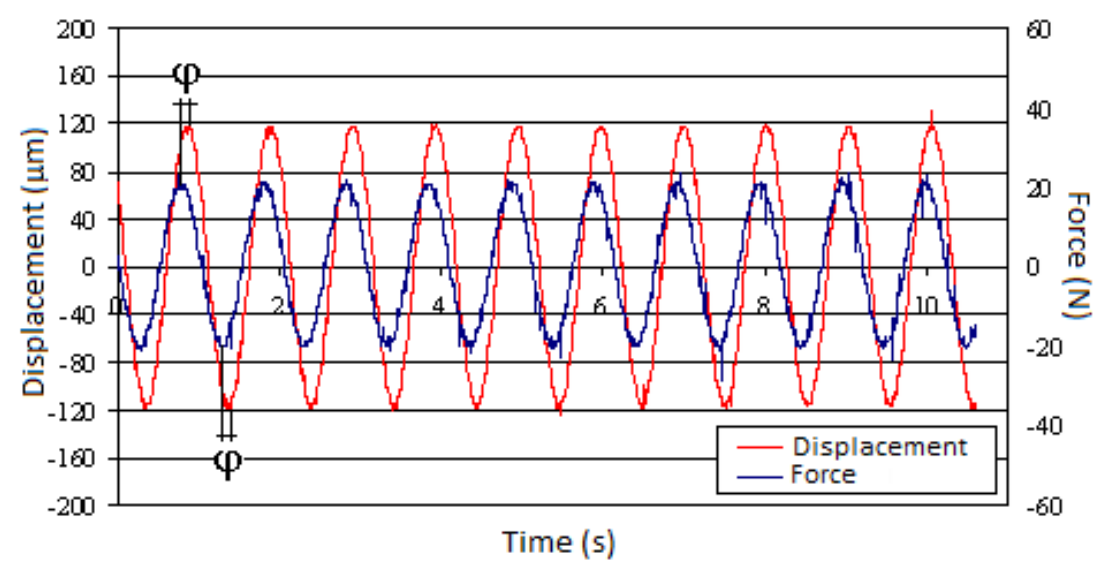

Figure 4. Displacement and force amplitudes captured by the loading cells and Hall Effect sensors, evidencing the phase angle $(\varphi)$ during complex modulus tests

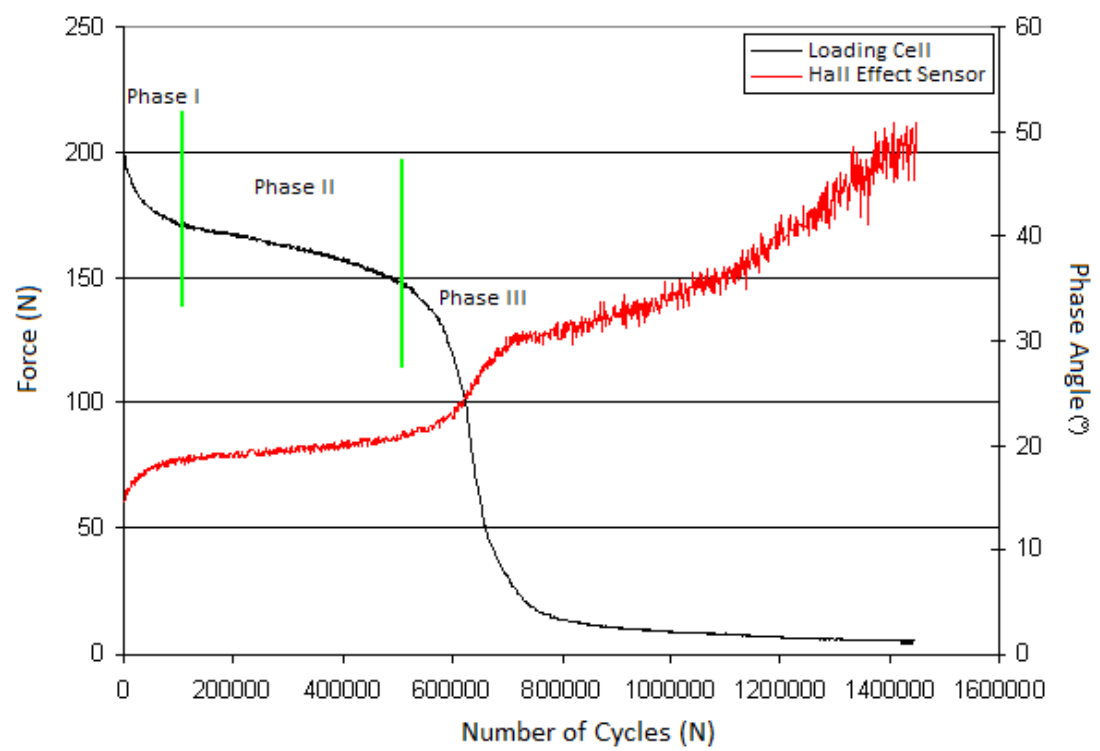

Figure 5. Evolution of the Force and Phase Angle $(\varphi)$ captured by the loading cells and Hall Effect sensors during fatigue tests

\section{VALIDATION PROCESS}

In order to establish the accuracy of the tests carried out by FADECOM apparatus, a scientific cooperation agreement was signed in 2015 and renewed in 2017 between GDPPav, representing UFSC, and IFSTTAR, from Nantes, France, to compare the results obtained by both research centres taking into account a laboratory campaign considering dynamic (complex) stiffness modulus and fatigue crossed-tests.

High modulus asphalt class 2 (EME2) mix with $0 / 12.7 \mathrm{~mm}$ granitic crushed rock gradation and use of asphalt binder penetration $10 / 20(0.1 \mathrm{~mm})$ was chosen to be tested. All trapezoidal specimens were produced in GDPPav laboratory premises, in order to avoid scattered procedures and to keep the homogeneity of the samples.

The planning of the tests followed the standardized French specifications (Manuel LPC, 2007; AFNOR NF EN 12697-24, 2012), which determine that at least 18 specimens (distributed equally among 3 different strain levels of evaluation) must be tested in a laboratory campaign on the fatigue behavior of a given asphalt mix and at least 4 specimens for carrying out complex modulus tests (AFNOR NF EN 12697-26, 2012). They were carried out tests just in dry state. 
In this particular research, 2 sets of 24 specimens were selected, distributed into 3 subsets of 8 units to be tested at each strain level for the fatigue tests, as well as 2 sets of 4 specimens for the complex modulus tests provided by the same asphalt mix slab.

However, to validate each set of specimens to be tested, they must comply with the limits defined by the rigorous statistical criteria of the standardized specifications. These criteria are the variation coefficient $(\leq 1.0 \%)$, which is based on the results for the constant $K_{\varepsilon}$ related to the geometric dimensions of each specimen, defined in Equation 1, and the standard deviation $(\leq 0.5)$ concerning the air void content of each set of specimens. If any specimen does not obey one of these criteria, it must be rejected before the beginning of the test and replaced by another suitable unit.

$$
\mathrm{K}_{\varepsilon}=\frac{(\mathrm{B}-\mathrm{b})^{2}}{8 \cdot b \cdot h^{2} \cdot\left[\frac{(\mathrm{B}-\mathrm{b}) \cdot(3 \mathrm{~B}-\mathrm{b})}{2 \mathrm{~B}^{2}}+\ln \frac{\mathrm{B}}{\mathrm{b}}\right]}
$$

where $\quad \mathrm{K}_{\varepsilon}: \quad$ constant related to the geometric dimensions of the specimens $\left[\mathrm{mm}^{-1}\right]$;

$\mathrm{h}$ : $\quad$ is the height of the specimen [mm];

b: $\quad$ is the small base of the specimen [mm]; and

B: $\quad$ is the large base of the specimen [mm].

The displacement amplitude applied by the oscillator rods on the small base of the trapezoidal specimens is calculated through Equation 2, which is related to each strain level chosen arbitrarily by the designer.

$$
\mathrm{f}=\frac{\varepsilon_{\max }}{\mathrm{K}_{\varepsilon}} \text {; being the displacement amplitude calculated by } \mathrm{A}=2 . \mathrm{f}
$$

where f: the half displacement amplitude applied to the small base of the specimen $\left[\mathrm{x} 10^{-6}\right]$;

$\mathrm{K}_{\varepsilon}: \quad$ constant related to the geometric values of the specimens $\left[\mathrm{mm}^{-1}\right]$;

$\varepsilon_{\text {max }}: \quad$ maximum strain level correspondent to a given displacement amplitude $\left[\mathrm{x} 10^{-6}\right]$;

A: peak to peak displacement amplitude applied to the small base of the specimen $\left[\mathrm{x} 10^{-6}\right]$.

It must be remarked that $10^{-6}$ is the scientific notation for microstrains ( $\mu \mathrm{def}$ ).

For fatigue tests, the adjustment of the displacement amplitude values calculated through Equation 2 (Table 1) was measured with an accuracy of $1.0 \mu \mathrm{m}$, using an analogical extensometer, which was placed on the top of the small base of the specimens.

For all complex modulus tests, the displacement amplitude was calculated using the same procedure considered for fatigue tests, but fixed at $40 \times 10-6$, respecting the standardized maximum limit of 50 x 10-6 (AFNOR NF EN 12697-26, 2012). Besides, frequencies of $1 \mathrm{~Hz}, 3 \mathrm{~Hz}, 10 \mathrm{~Hz}$ and $30 \mathrm{~Hz}$ were applied. For each frequency, temperatures of $-10^{\circ} \mathrm{C}, 0^{\circ} \mathrm{C}, 10^{\circ} \mathrm{C}, 15^{\circ} \mathrm{C}, 20^{\circ} \mathrm{C}, 30^{\circ} \mathrm{C}$, $40^{\circ} \mathrm{C}$ and $50^{\circ} \mathrm{C}$ were simulated. The displacement amplitudes were gradually regulated by two Allen head screws connected to each eccentric axle (indication 2 in Figure 1).

As a result of this laboratory campaign, Figure 6 presents the rheological behavior of the dynamic stiffness modulus represented in complex plan so-called Cole-Cole, comprising its real (E1) and imaginary (E2) components, while Figure 7 presents the fatigue resistance tests. 
Table 1 - Strain levels chosen for fatigue tests and air void content of the asphalt mixes

\begin{tabular}{|c|c|c|c|c|c|}
\hline \multirow{3}{*}{ Asphalt Mix } & \multirow{3}{*}{$\begin{array}{c}\text { Temperature of } \\
\text { Test }\end{array}$} & \multicolumn{3}{|c|}{ Strain Level $\left(\times 10^{-6}\right)$} & \multirow[t]{2}{*}{ Air Void Content (\%) } \\
\hline & & \multicolumn{3}{|c|}{ Sets of Specimens } & \\
\hline & & 8 & 8 & 8 & \\
\hline $10 / 20$ & $10 \div \mathrm{C}$ & 120 & 135 & 150 & 4.2 \\
\hline $10 / 20$ & $30 \circ \mathrm{C}$ & 95 & 115 & 135 & 4.3 \\
\hline
\end{tabular}

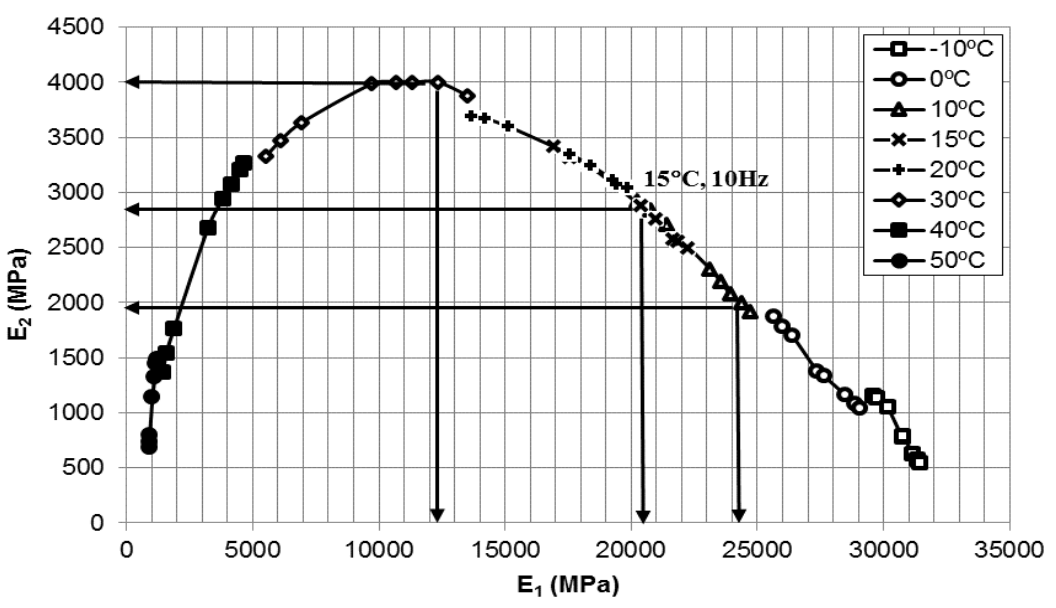

Figure 6. Rheological behavior of the asphalt mix in complex plan Cole-Cole

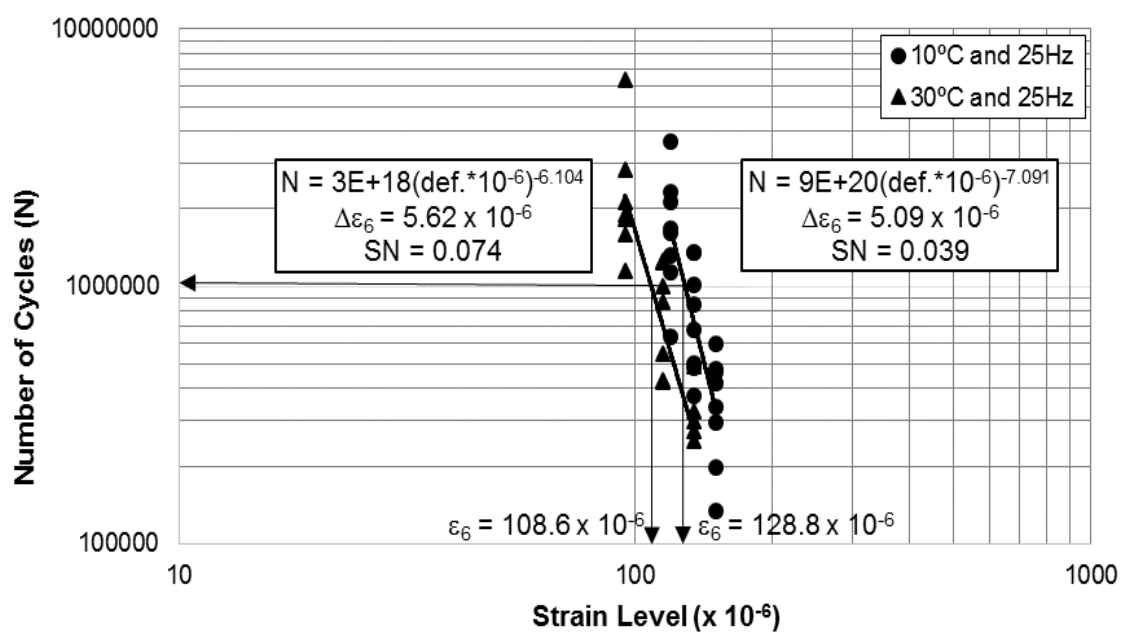

Figure 7. Fatigue curves from tests carried out at $10^{\circ} \mathrm{C}$ and $25 \mathrm{~Hz}$, and at $30^{\circ} \mathrm{C}$ and $25 \mathrm{~Hz}$

Table 2 summarizes the results obtained by the FADECOM and IFSTTAR apparatuses.

Table 2 - Strain levels chosen for fatigue tests and air void content of the asphalt mixes

\begin{tabular}{|c|c|c|c|c|c|c|c|c|}
\hline \multicolumn{9}{|c|}{ Dynamic Complex Stiffness Modulus Tests } \\
\hline Test Condition & $\begin{array}{c}E_{1}{ }^{1} \\
(\mathrm{MPa})\end{array}$ & $\begin{array}{c}E_{1}^{2} \\
(\mathrm{MPa})\end{array}$ & $\begin{array}{c}E_{2}^{1} \\
(\mathrm{MPa})\end{array}$ & $\begin{array}{c}E_{2}{ }^{2} \\
(\mathrm{MPa})\end{array}$ & $\begin{array}{l}\left|E^{*}\right|^{1} \\
(\mathrm{MPa})\end{array}$ & $\begin{array}{l}\left|\mathrm{E}^{*}\right|^{2} \\
(\mathrm{MPa})\end{array}$ & $\varphi^{1}\left({ }^{\circ}\right)$ & $\varphi^{2}\left({ }^{\circ}\right)$ \\
\hline $10^{\circ} \mathrm{C}$ and $25 \mathrm{~Hz}$ & 24786 & 24516 & 2031 & 2339 & 24871 & 24627 & 4.7 & 5.5 \\
\hline $15^{\circ} \mathrm{C}$ and $10 \mathrm{~Hz}$ & 20719 & 19697 & 2917 & 3054 & 20926 & 19932 & 8.0 & 8.8 \\
\hline $30^{\circ} \mathrm{C}$ and $25 \mathrm{~Hz}$ & 12020 & 10703 & 4018 & 3651 & 12677 & 11309 & 18.5 & 18.6 \\
\hline \multicolumn{9}{|c|}{ Fatigue Tests } \\
\hline Test Condition & \multicolumn{4}{|c|}{$\varepsilon_{6}\left(x 10^{-6}\right)^{1}$} & \multicolumn{4}{|c|}{$\varepsilon_{6}\left(x 10^{-6}\right)^{2}$} \\
\hline $10^{\circ} \mathrm{C}$ and $25 \mathrm{~Hz}$ & \multicolumn{4}{|c|}{128.8} & \multicolumn{4}{|c|}{130.2} \\
\hline $30^{\circ} \mathrm{C}$ and $25 \mathrm{~Hz}$ & \multicolumn{4}{|c|}{108.6} & \multicolumn{4}{|c|}{-} \\
\hline
\end{tabular}




\section{CALCULUS OF THE ADMISSIBLE STRAIN}

The results obtained in laboratory, more specifically those of complex modulus and fatigue tests, are directly inserted in numerical simulations by using Huet-Sayegh rheological model (Figure 8, Equation3), as well as in the admissible strain calculus (Equation 4), with support of the computerized tools Viscoanalyse Ver. Beta and Viscoroute 2.0, considering cyclic loading applications.

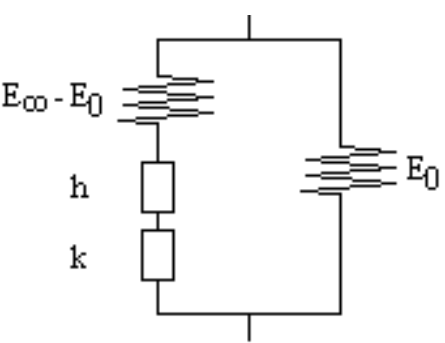

Figure 8. Huet-Sayegh rheological model

$$
\mathrm{E}^{*}(\omega)=\mathrm{E}_{0}+\frac{\mathrm{E}_{\infty}-\mathrm{E}_{0}}{1+\delta(i \omega \tau)^{-\mathrm{k}}+(i \omega \tau)^{-\mathrm{h}}}
$$

where $\quad \mathrm{i}$ : complex number defined by $\mathrm{i}^{2}=-1$, which indicates the imaginary component of the complex modulus;

$\mathrm{E}_{\infty}$ : instantaneous modulus, obtained when $\omega \tau$ tends to the infinite, considering higher frequencies and lower temperatures in loading application conditions;

E0: $\quad$ static modulus, considering lower frequencies and higher temperatures in loading application conditions; ' $\tau$ ' concerns the relaxation time of the bumpers ' $h$ ' and ' $k$ ', thus, a parameter dependent of the time and resembling to a delay time, in which the value varies with the temperature $\tau=\exp \left(A_{0}+A_{1} \cdot \theta+A_{2} . \theta^{2}\right)$, being $\theta$ the temperature and $A_{0}$, $A_{1}$ and $A_{2}$ constants determined experimentally;

$\mathrm{h}$ and $\mathrm{k}$ : parabolic elements of the model, where for asphalt mixes they comprise the range $0<\mathrm{k}<\mathrm{h}<1$;

$\delta: \quad$ dimensionless constant, which depends on the asphalt binder nature and on the aggregate gradation curve; and $\omega=2 \pi \mathrm{f}$, being $\mathrm{f}=$ loading application frequency (pulsation).

$$
\varepsilon\left(\mathrm{NE}, \theta_{\mathrm{eq}}, \mathrm{f}\right)=\varepsilon_{6}\left(10^{\circ} \mathrm{C}, 25 \mathrm{~Hz}\right) \cdot\left[\mathrm{E}^{*}\left(10^{\circ} \mathrm{C}\right) / \mathrm{E}^{*}\left(\theta_{\mathrm{eq}}\right)\right]^{0,5} \cdot\left(\mathrm{NE} / 10^{6}\right)^{\mathrm{b}} \cdot \mathrm{k}_{\mathrm{r}} \cdot \mathrm{k}_{\mathrm{s}} \cdot \mathrm{k}_{\mathrm{c}}
$$

Where $\quad \varepsilon\left(\mathrm{NE}, \theta_{\mathrm{eq}}, \mathrm{f}\right)$ :

admissible strain of the asphalt mix regarding a given number of loading cycles (NE), equivalent temperature $\left(\theta_{\text {eq }}\right)$ and loading frequency (f);

$\varepsilon_{6}(\theta, f): \quad$ strain level at $10^{6}$ cycles at a given temperature $(\theta)$ and loading frequency (f), considered as $10^{\circ} \mathrm{C}$ and $25 \mathrm{~Hz}$, respectively, in France;

$\left(\mathrm{NE} / 10^{6}\right)^{\mathrm{b}}$ : $\quad$ number of loading cycles predicted to be applicated on the 
asphalt mix during its service life, in relation to the standard criterion of $10^{6}$ cycles and the slope ' $b$ ' concerning the fatigue tests;

$\left[E^{*}(\theta) / E^{*}\left(\theta_{\text {eq }}\right)\right]^{0,5}: \quad$ square root between complex moduli determined at a given temperature $(\theta)$ and at a temperature considered as equivalent $\left(\theta_{\mathrm{eq}}, 1^{\circ} \mathrm{O} \mathrm{C}\right.$ in France);

$\mathrm{kr}, \mathrm{ks}_{\mathrm{s}}, \mathrm{k}_{\mathrm{c}}$ :

failure risk, heterogeneity minority and adjust coefficients, respectively (Equations 5 and 6).

$$
\begin{gathered}
\mathrm{k}_{\mathrm{r}}=10^{-\mathrm{ub} \delta} \\
\delta=\left[\mathrm{SN}^{2}+\left(\mathrm{c}^{2} / \mathrm{b}^{2}\right) \mathrm{Sh}^{2}\right]^{0,5}
\end{gathered}
$$

where $\quad \mathrm{k}_{\mathrm{r}}$ : failure risk coefficient;

$\delta$ : $\quad$ standard deviation associated to $\mathrm{SN}, \mathrm{b}$, Sh e c;

$\mathrm{SN}$ : $\quad$ standard deviation regarding the number of cycles supported by the asphalt mix during fatigue tests $\log (\mathrm{N})$;

$\mathrm{u}$ : $\quad$ statistical factor (fractile) of the normal series associated to the assumed risk $\left(\log \mathrm{N} / \mathrm{N}_{50 \%}\right)$

b: fatigue exponent slope;

Sh: $\quad$ standard deviation concerning the thickness layer all over the pavement structure;

c: coefficient which correlates the strain (or strength) variation in the pavement structure to alleatory thickness variation $\Delta \mathrm{h}\left(\log \varepsilon=\log \varepsilon_{0}-\mathrm{c} . \Delta \mathrm{h}\right)$, in which for ordinary pavement structures is assumed as $0,02 \mathrm{~cm}^{-1}$.

The parameters for defining the fractile ' $u$ ' associated to a given percent of failure risk assumed, as well as 'Sh', ' $\mathrm{k}_{\mathrm{s}}$ ' and ' $\mathrm{k}_{\mathrm{c}}$ ' are presented in Tables 3, 4, 5 and 6, respectively.

It is important to clarify that for calculating the admissible strain at $10^{6}$ loading cycles ' $\varepsilon(\mathrm{NE}$, $\theta_{\text {eq }}, \mathrm{f}$ )' with use of Equation 4, French design methodology considers negligible the direct correspondence between field measurements taken normally at $10 \mathrm{~Hz}$ in the bottom of the field asphalt concrete layers and those determined at $25 \mathrm{~Hz}$ in laboratory tests, taking into account usual temperatures of service (Guide Tecnhique, 1997).

Table 3 - Percent of failure risk assumed for asphalt concrete pavement structures regarding the fractile ' $u$ ' (Guide Technique, 1997)

\begin{tabular}{llllll}
\hline Fractile $(\mathrm{u})$ & $-0,84$ & $-1,04$ & $-1,28$ & $-1,65$ & $-2,05$ \\
\hline Risk $(\%)$ & 20 & 15 & 10 & 5 & 2 \\
\hline
\end{tabular}

Table 4 - Sh' values assumed for asphalt concrete pavement structures regarding the entire bituminous thickness designed (Guide Technique, 1997)

\begin{tabular}{llll}
\hline Stiffness Modulus (E) & $\mathrm{E}<50 \mathrm{MPa}$ & $50 \mathrm{MPa} \leq \mathrm{E}<120 \mathrm{MPa}$ & $\mathrm{E} \geq 120 \mathrm{MPa}$ \\
\hline $\mathrm{K}_{\mathrm{s}}$ & $1 / 1.2$ & $1 / 1.1$ & 1 \\
\hline
\end{tabular}


Table 5 - Values assumed for the coefficient ' $k_{s}$ ' (Guide Technique, 1997)

\begin{tabular}{llll}
\hline Thickness $(\mathrm{cm})$ & $\mathrm{e} \leq 10$ & $10<\mathrm{e}<15$ & $15 \leq \mathrm{e}$ \\
\hline Sh $(\mathrm{cm})$ & 1 & $1+0,3(\mathrm{e}-10)$ & 2,5 \\
\hline
\end{tabular}

Table 6 - Values assumed for the coefficient ' $\mathrm{k}_{\mathrm{c}}$ ' (Guide Technique, 1997)

\begin{tabular}{ll}
\hline Material & $\mathrm{k}_{\mathrm{c}}$ \\
\hline Road base asphalt concrete (GB) & 1.3 \\
\hline Bituminous concrete (BB) & 1.1 \\
\hline High modulus asphalt concrete (EME) & 1.0 \\
\hline
\end{tabular}

However, the coefficient ' $k c$ ' is predicted in the above-mentioned Equation 4, in order to adjust the mathematical model used in laboratory to the mechanical behavior evaluated in the field, since true-scale pavement section tests, which have been carried out over three decades with a fatigue carroussel framework, being responsible to assure a narrow field/laboratory ratio (Table 6), thus, adjusting eventual scatters between measurements realized at $10 \mathrm{~Hz}$ and at 25Hz (El Abd, 2006).

These technical procedures allowed determining the viscoelastic linear parameters and mechanical behavior in pavement structure design regarding the asphalt mix tested.

\section{NUMERICAL SIMULATIONS ON DESIGNING PAVEMENT STRUCTURE}

For simulating the mechanical behavior of the asphalt mix formulated in this research (EME2), a pavement structure was designed based on French methodology concepts (Guide Technique, 1997) according to the following technical parameters: annual average daily traffic flow (MJA) of 6.000 heavy trucks (class TC8) with $130 \mathrm{kN}$ double-wheeling standard single axle load each, applying cyclic loadings at $72 \mathrm{~km} / \mathrm{h}$.

A cumulative traffic (NE) of $8.34 \times 107$ was predicted to be supported along 30 years, considering $15 \%$ of failure risk $(\mathrm{kr}=0.887$ at $10 \mathrm{C}$ and $25 \mathrm{~Hz})$, besides $1 / 1.1$ related to heterogeneity minority (ks) and 1.0 to adjust (kc) coefficients mentioned earlier in section 4 .

They were considered a foundation platform from class 3 (PF3) with a stiffness modulus of $100 \mathrm{MPa}$ and $30.0 \mathrm{~cm}$ of subgrade reinforcement layer in soil treated with lime, while sub-base and base layers with high modulus asphalt mix or also so-called Enrobé Bitumineux à Module Élevé class 2 (EME2), taking into account the formulation tested in the experimental campaign carried out and described in earlier sections. For EME2, thickness layers from $9.0 \mathrm{~cm}$ to $13.0 \mathrm{~cm}$ were simulated following standardized recommendations (Catalogue LCPC/SETRA, 1998).

Table 7 - Rheological Parameters from Huet-Sayegh model for EME2

\begin{tabular}{ll}
\hline Huet-Sayegh Model Parameters & Results for EME2 \\
\hline E & $32215.90 \mathrm{MPa}$ \\
$\mathrm{E}_{0}$ & $139.938 \mathrm{MPa}$ \\
$\mathrm{k}$ & 0.205 \\
$\mathrm{~h}$ & 0.65009 \\
$\delta$ & 1.25729 \\
$\mathrm{~A}_{0}$ & 4.45615 \\
$\mathrm{~A}_{1}$ & -0.345861 \\
$\mathrm{~A}_{2}$ & 0.0014058 \\
$\tau$ & 0.65009 \\
\hline
\end{tabular}


Rheological parameters of the asphalt mix EME2 were determined with use of Huet-Sayegh viscoelastic linear model (Eq. 3) simulated in the computerized tool so-called Viscoanalyse Ver. Beta (Table 7), considering results from complex modulus tests presented in Figure 4 and Table 2. Complex modulus and fatigue test results used in the numerical simulations are compiled in Table 8.

Table 8 - Complex Modulus and Fatigue Test Results for EME2.

\begin{tabular}{ccccc}
\hline \multirow{2}{*}{ Test Condition } & \multicolumn{3}{c}{ Complex Modulus } & \multicolumn{3}{c}{ Fatigue } \\
\cline { 2 - 5 } & $\left|\mathrm{E}^{*}\right|(\mathrm{MPa})$ & $\varepsilon_{6}\left(\times 10^{-6}\right)$ & $\mathrm{SN}$ & $1 / \mathrm{b}$ \\
\hline $10^{\circ} \mathrm{C}$ e $10 \mathrm{~Hz}$ & 23612 & - & - & - \\
$15^{\circ} \mathrm{C}$ e $10 \mathrm{~Hz}$ & 20926 & - & - & - \\
$10^{\circ} \mathrm{C}$ e $25 \mathrm{~Hz}$ & - & 128.8 & 0.039 & 0.14 \\
\hline
\end{tabular}

Furthermore, according to Guide Tecnhique (1997), when it is being designed an asphalt concrete pavement structure able to support heavy traffic flows, it must be evaluated not only the admissible tensile strain in the bottom of the deepest asphalt layer ' $\varepsilon\left(N E, \theta_{\text {eq }}, f\right)$ ' calculated by Equation 4, but also the admissible vertical compression strain ' $\varepsilon_{\text {z,ad' }}$ on the top of the foundation platform (PF), as defined in Equation 7.

$$
\varepsilon_{\mathrm{z}, \mathrm{ad}}=0,012(\mathrm{NE})^{-0,222}
$$

where $\quad \varepsilon_{\mathrm{z}, \mathrm{ad}}$ admissible vertical compression strain on the top of the foundation platform (PF);

NE: $\quad$ cumulative traffic concerning $130 \mathrm{kN}$ standard double-wheeling single axle load.

The development of numerical simulations interacting Huet-Sayegh rheological linear viscoelastic model and mechanical behavior at cyclic loading applications on the designed pavement structure was carried out with use of computerized tool so-called Viscoroute 2.0, in which the results are presented in Table 9 and illustrated in Figure 9.

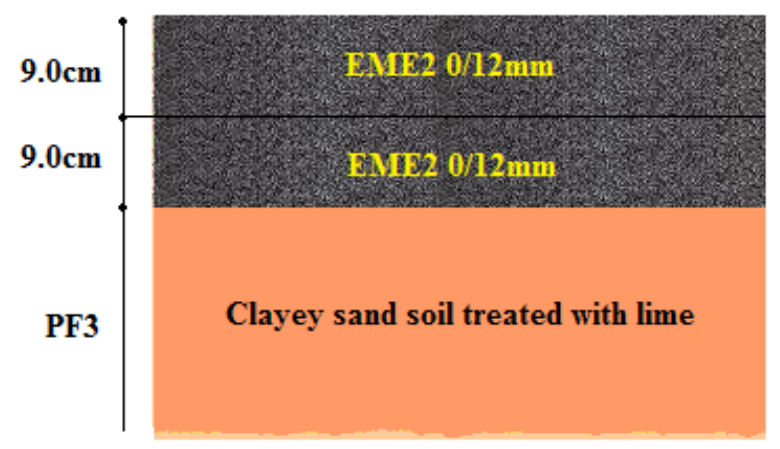

Figure 8. Huet-Sayegh rheological model

The results presented in Table 9 indicate numerical simulation routine values of ' $\varepsilon_{\mathrm{t}}$ ' and ' $\varepsilon_{\mathrm{z}}$ ' minor than the admissible calculated limits ' $\varepsilon\left(\mathrm{NE}, \theta_{\mathrm{eq}}, \mathrm{f}\right)$ ' and ' $\varepsilon_{\mathrm{z}, \mathrm{ad}}$ ', considering initial asphalt layer thicknesses of $9.0 \mathrm{~cm}$, as well as complex modulus ratio ' $\left[\mathrm{E}^{*}(\theta) / \mathrm{E}^{*}\left(\theta_{\mathrm{eq}}\right)\right]^{0,5^{\prime}}$ with $\mathrm{E}^{*}(\theta)=10^{\circ} \mathrm{C}$ and $\mathrm{E}^{*}\left(\theta_{\mathrm{eq}}\right)=15^{\circ} \mathrm{C}$, both determined at $10 \mathrm{~Hz}$, and fatigue ' $\varepsilon 6^{\prime}$ obtained at $10^{\circ} \mathrm{C}$ and $25 \mathrm{~Hz}$, thus, being in accordance to French traditional pavement design standard principles predicted in Guide Technique (1997). 
Table 9 - Results obtained in numerical simulations

\begin{tabular}{|c|c|c|c|c|c|}
\hline \multirow{2}{*}{$\begin{array}{c}\text { Test Condition } \\
\text { (Numerical Simulation Routines) }\end{array}$} & \multirow{2}{*}{ Thickness (cm) } & \multicolumn{2}{|c|}{ Admissible Calculated Values } & \multicolumn{2}{|c|}{$\begin{array}{c}\text { Numerical Simulation } \\
\text { Results }\end{array}$} \\
\hline & & $\begin{array}{c}\varepsilon\left(\mathrm{NE}, \theta_{\mathrm{eq}}, \mathrm{f}\right) \\
\left(\times 10^{-6}\right)\end{array}$ & $\begin{array}{c}\left(\varepsilon_{z, \mathrm{ad}}\right)(\mathrm{x} \\
\left.10^{-6}\right)\end{array}$ & $\begin{array}{c}\left(\varepsilon_{t}\right) \\
\left(\times 10^{-6}\right)\end{array}$ & $\begin{array}{c}\left(\varepsilon_{z}\right) \\
\left(\times 10^{-6}\right)\end{array}$ \\
\hline \multicolumn{6}{|l|}{$\varepsilon_{6}=10^{\circ} \mathrm{C}$ and $25 \mathrm{~Hz}$} \\
\hline $\mathrm{E}^{*}(\theta)=10^{\circ} \mathrm{C}$ and $10 \mathrm{~Hz}$ & $9.0 \mathrm{~cm} / 9.0 \mathrm{~cm} *$ & 59.32 & -209.26 & 55.08 & -56.49 \\
\hline $\mathrm{E}^{*}\left(\theta_{\mathrm{eq}}\right)=15^{\circ} \mathrm{C}$ and $10 \mathrm{~Hz}$ & & & & & \\
\hline
\end{tabular}

\section{Legend:}

*Thickness $(\mathrm{cm})$ in order: base/sub-base asphalt layers (2 layers).

$\varepsilon_{\mathrm{t}}$ tensile strain in the bottom of the deepest asphalt layer.

$\varepsilon\left(N E, \theta_{\text {eq }}, f\right)$ : admissible tensile strain in the bottom of the deepest asphalt layer calculated with use of Equation 3.

$\varepsilon_{z}$ : compression strain on the top of the platform foundation.

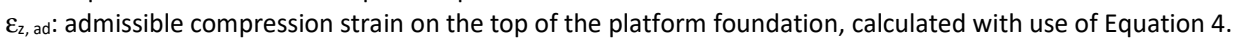

Sign convention of Viscoroute 2.0: (+) tensile and (-) compression.

\section{CONCLUSIONS}

Analyzing data presented in this research, it is possible to infer that the scattering of results is less than $5.0 \%$ for dynamic (complex) stiffness modulus (| $\mathrm{E}^{*} \mid$ ), less than $1.0 \%$ for phase angle $\left(\stackrel{\circ}{)}\right.$ and $1.0 \%$ maximum for fatigue strain at $10^{6}$ loading cycles $(\varepsilon 6)$, when compared the values determined by the FADECOM and IFSTTAR apparatuses. These trends are strongly lower than the standard deviation tolerances established by the French methodology, i.e., around 10\% maximum for stiffness modulus and $3.0\left(\times 10^{-6}\right)$ for $\varepsilon_{6}\left(\times 10^{-6}\right)$, demonstrating huge accuracy of the FADECOM apparatus and its feasibility to be applied in pavement design researches.

Furthermore, it was demonstrated that from a suitably validated apparatus, such as FADECOM, it can be concluded that French pavement design methodology presents a versatile aspect, because it can be adaptated to the actual context of other regions or countries worldwide, even in South America, for instance, since the appropriated particular parameters related to each place be researched and inserted correctly in the constitutive equations presented, taking into account a narrow field/laboratory rate, followed up by true-scale tests and deep knowledge on the mechanical and rheological behaviours of local materials.

\section{ACKNOWLEDGEMENTS}

We would like to thank to the Institut Français des Sciences et Technologies des Transports, de l'Aménagement et des Réseaux (IFSTTAR) from Nantes, France, by the continuous scientific cooperation agreement with our Group of Research and Development in Pavement (GDPPav), to Petrobrás for financing the project concerning the development of FADECOM apparatus (Cooperation Agreement 0050.0075479.12.9 and SAP n-4600373381), as well as to Gustavo Momm by the decisive collaboration along the mechanical and logical conception of the FADECOM apparatus.

\section{REFERENCES}

AFNOR NF EN 12697-24 (2012) Mélanges Bitumineux: Méthode d'Éssai pour Mélange Hydrocarboné à Chaud - Partie 24: Essai par Flexion à Flèche Constante. 32p. Association Française de Normalisation. France.

AFNOR NF EN 12697-26 (2012) Mélanges Bitumineux: Méthode d'Éssai pour Mélange Hydrocarboné à Chaud - Partie 26: Module de Rigidité. 40p. Association Française de Normalisation. France.

Barra, B.; Momm, L.; Guerrero, Y.; Al-Qureshi, H. A.; Mikowski, A.; Michels, R. (2016) Temperature implications on rheologicalmechanical behavior and design of high modulus dense asphalt mix. Construction \& Building Materials, v. 125, p. 135-144, 2016. DOI: 10.1016/j.conbuildmat.2016.08.037.

Barra, B.; Momm, L.; Guerrero, Y.; Bernucci, L. L. B. (2012) Fatigue Behavior of Dense Asphalt Mixes in Dry and EnvironmentalConditioning States. Construction \& Building Materials, v. 29, p. 128-134. DOI: 10.1016/j.conbuildmat.2011.10.003.

Barra, B. (2009) Avaliação da Ação da Água no Módulo Complexo e na Fadiga de Misturas Asfálticas Densas. PhD Thesis presented to Federal University of Santa Catarina (UFSC), 327p. 
Catalogue LCPC/SETRA (1994) Catalogue des Structures Types de Chaussées Neuves: Réseau Routière National. Laboratoire Central des Ponts et Chaussées (LCPC) en partenariat avec le Service d'Étude Technique des Routes et Autoroutes (SETRA). Paris, France.

Domec, V. (2005) Endommagement par fatigue des enrobés bitumineux em condition de trafic simulé et de température. Thèse de Docteur. Université de Bordeaux I. 426p.

Guide Technique (1997), French Design Manual for Pavement Structures (English Version). Published by Service d'Études Techniques des Routes et Autoroutes (SETRA) and Laboratoire Central des Ponts et Chaussées (LCPC), 248 p. Paris, France.

Huet, C. (1963) Étude par une méthode d'impédance du comportement viscoélastique des materiaux hydrocarbonés. Thèse de Docteur. Faculté des Sciences de l'Université de Paris. 58p.

Manuel LPC (2007) Manuel LPC d'aide à la formulation des enrobés. Groupe de Travail RST “Formulation des enrobés”. 320p. Laboratoire Central des Ponts et Chaussées. Paris, France.

Momm, L. (1998) Estudo dos Efeitos da Granulometria Sobre a Macrotextura Superficial do Concreto Asfáltico e Seu Comportamento Mecânico. PhD Thesis presented to Polytecnhical School of University of São Paulo (USP), 357p.

Rudensky, A. V. (1997) Asphalt concrete fatigue properties, in Proceedings of the 5th International RILEM Symposium. Mechanical Tests for Bituminous Materials (MBTM): Recent Improvements and Future Prospects. Lyon, France, pp. 10581066.

Sayegh, G. (1965) Contribution à l'étude des propriètés viscoélastiques des bitumes purs et des bétons bitumineux. Thèse de Docteur Ingénieur. Faculté des Sciences de Paris. 206p. 